\begin{tabular}{|c|c|c|}
\hline KULTURA & $\begin{array}{l}\text { POLSKA AKADEMIA NAUK } \\
\text { KOMITET SOCJOLOGII } \\
\text { INSTYTUT STUDIÓW POLITYCZNYCH }\end{array}$ & ISSN 0023-5172 \\
\hline & KULTURA CODZIENNOŚCI - CODZIEN & \\
\hline
\end{tabular}

MICHAE FALKOWSKI

Uniwersytet im. Adama Mickiewicza w Poznaniu

\title{
ŻYCIE CODZIENNE W SAMOCHODZIE \\ SCHEMATY INTERAKCJI I WZAJEMNEGO POSTRZEGANIA SIĘ KIEROWCÓW Z PERSPEKTYWY SOCJOLOGII ŻYCIA CODZIENNEGO
}

Świat człowieka to świat społeczny istniejący i stale odtwarzany w ramach kultury, w ramach cywilizacji. Ludzie tworzą kulturę i egzystują w niej, a aby było to możliwe, muszą się między sobą komunikować, porozumiewać, przekazywać informacje i wiedzę. I czynią to nieustannie. Każdy aspekt życia społecznego, każda interakcja społeczna jest związana z komunikowaniem, które tworzy sieć związków społecznych.

Informacje między ludźmi, przekazywane są zarówno w postaci znaków, jak i jednostkowych zachowań, które mogą być swoistym symptomem tego, co dana jednostka myśli czy jakie działania zamierza podjąć. Sprawność czy efektywność komunikowania ma ogromne znaczenie dla funkcjonowania społeczeństwa. Społeczeństwo funkcjonuje w zgodzie z jakimś porządkiem. Sens rzeczywistości społecznej, sens życia społecznego jest ustalany przez ludzi w codziennych, zwyczajnych działaniach.

Jedną z przestrzeni porządku społecznego tworzonego codziennie i bezustannie w praktykach ludzkich jest ruch samochodowy oraz interakcje i komunikacja wzajemna wśród kierowców samochodów. W tej przestrzeni ludzie spędzają coraz więcej czasu, odtwarzając i tworząc nowe schematy interakcji oraz typowe dla tej rzeczywistości kody komunikacyjne. Jest to pewien element codziennej rzeczywistości wielu z nas, a dla niektórych, na przykład dla zawodowych kierowców, być może jednen $z$ ważniejszych aspektów porządku społecznego.

Świat samochodów i ruchu drogowego jest dla kierowców ich światem codziennym. Realizują tu typowe działania w typowych sytuacjach społecznych. To tu ma miejsce ich rzeczywiste ludzkie doświadczenie, tu percypują

Adres do korespondencji: michalf@list.pl 
rutynowe i oczywiste aspekty życia, często przyjmując je bezrefleksyjnie (zob. Sztompka 2007, s. 31-32). Współegzystują z innymi, wchodząc w rozmaite interpersonalne relacje, a jazda i kierowanie samochodem przebiega zwykle według znanego kierowcy scenariusza, który nie wzbudza wątpliwości, choć może wywoływać całą gamę uczuć i emocji. Jadący w strumieniu innych pojazdów i kierowców przestają zastanawiać się nad sytuacją, w której się znajdują. Owa przyjmowana bez zastrzeżeń oczywistość daje kierującym poczucie normalności.

Kierowcy komunikują się między sobą w charakterystyczny dla swego świata sposób. Stworzona przez nich rzeczywistość jest istotnym elementem rzeczywistości społecznej. W przestrzeniach kabin prowadzonych pojazdów jednostki przebywają często i długo, tym samym owa rzeczywistość jest ich codziennością. Postrzegają świat z perspektywy samochodu i nie wzbudza to w nich wątpliwości - jest to świat ich życia codziennego.

Owa „samochodowa rzeczywistość” może być analizowana z różnych perspektyw, zarówno w kontekście założeń semiologii, jak i socjologii życia codziennego.

Po pierwsze, sam samochód można potraktować jako znak albo węziej jako funkcjoznak. Jak wszystkie inne przedmioty wykracza on poza działanie ludzkie i służy do przekazywania znaczeń — jest wytworem kultury, która jednocześnie określa sposoby jego wykorzystania, obejmujące między innymi ową „funkcjoznaczność" (Dant 2007, s. 25). Marka, rodzaj, typ, kolor, specyficzne oznakowanie czy doznakowanie mogą być nośnikiem wielu znaczeń i równie wielu interpretacji.

Po wtóre, na postrzeganie owej nośności znaczeń samochodu i jego symbolicznej wymowy można spojrzeć z perspektywy socjologii przedmiotów. Trzeba wtedy założyć, że doświadczanie rzeczywistości społecznej przebiega za pośrednictwem dóbr materialnych lub ich reprezentacji, a przedmioty są potrzebne do poznania, zrozumienia owej rzeczywistości oraz funkcjonowania w niej (Krajewski 2008, s. 521). Między ludźmi a przedmiotami zachodzą interakcje o charakterze społecznym, ponieważ przedmioty są nie tylko fizycznymi wytworami kultury, ale również wytworami społecznymi - jako elementy określonego porządku, codziennych zwyczajów czy sposobów życia (Dant 2007, s. 25-26). Samochód w tej perspektywie jest zatem zarówno artefaktem pełniącym konkretną funkcję użytkową, jak i obiektem wielu interpretacji wyrażającym własności otaczającej rzeczywistości, równoprawnym jej podmiotem, stanowiącym część kontekstu życia społecznego (Dant 2007, s. 26). Ma z jednej strony wymowę symboliczną, przenosi określone znaczenia społeczne, a $z$ drugiej powoduje jakieś zachowania, czy też prowokuje do nich, a jego posiadacz może odpowiednio tym procesem zarządzać.

Po trzecie, analizie można poddać systemy i schematy komunikowania się między kierowcami, charakterystyczne dla tej rzeczywistości kody oraz sposoby porozumiewania się i wzajemnego przekazywania informacji. Badać tu 
można to, czy kierowcy rzeczywiście wpółegzystują w przestrzeni tych samych symboli i znaczeń, czy wzajemnie się rozumieją i czy w ogóle chcą się rozumieć, a także to, jakimi sposobami próbują wchodzić w interakcje, niesłychanie krótkie i przelotne, ale czasem jakże istotne.

Po czwarte, można dokonywać próby rekonstrukcji sposobów zachowania się na drodze, swoistych „praktyk jeżdżenia”, zwyczajów drogowych czy stylów jazdy, a także ich znajomości przez kierujących oraz ich stosunku do zarówno samych praktyk, jak i prezentujących je kierowców.

Interakcje między kierowcami, to, co dzieje się nieustannie w społecznych sytuacjach ruchu drogowego, w ich komunikacji i wzajemnym wpływie i oddziaływaniu, w wyrażanych postawach i stereotypach, będą przedmiotem poniższych rozważań.

Samochód, mocno nacechowany symbolicznie wynalazek z przełomu XIX i XX wieku, w życiu ludzi zajmuje ważne miejsce. Zdominował inne rodzaje mobilności, zreorganizował myślenie o możliwościach i ograniczeniach związane z odległościami między różnymi miejscami, ma też olbrzymi wpływ na degradację środowiska naturalnego (Urry 2008 s. 412). Jest, czy też miał być w założeniach jego konstruktorów, środkiem służącym do łatwego przemieszczania się, ale nie tylko. Cieszy się również statusem symbolu czy ikony. Jest jednym z głównych, zaraz po mieszkaniu czy domu, produktów konsumpcji nadających ich właścicielowi status przez swą wartość symboliczną, jest elementem infrastruktury i przedmiotem olbrzymiej gałęzi przemysłu. $Z$ przemysłu motoryzacyjnego wywodzi się forma organizacji pracy zwana fordyzmem. Różnorodne cechy kojarzone $z$ markami czy modelami samochodów oraz niezliczone sytuacje i praktyki związane $z$ samochodami przenikają kulturę popularną pojawiają się w filmach, programach telewizyjnych i radiowych, książkach, gazetach, czasopismach, reklamach, kalendarzach, plakatach, teledyskach itp.

Samochód stał się też dla wielu ludzi elementem „drugiej natury” — przedłużeniem ich samych. Są do niego tak przyzwyczajeni, iż użytkować go mogą bezrefleksyjnie, a co za tym idzie - kierowanie pojazdem i ruch uliczny stały się ich integralną częścią (Edensor 2004, s. 155). Mobilność — czy wręcz „automobilność" - jest konstytutywnym elementem nowoczesności oraz integralną częścią sposobu opanowania przez ludzi świata (Edensor 2004 s. 156), kierowcę zaś postrzegać można jako hybrydowe zestawienie człowieka z maszyną oraz drogą, infrastrukturą i całą kulturą mobilności (zob. Urry 2008, s. 413).

Samochód, jak zresztą mnóstwo innych wytworzonych przez człowieka przedmiotów, jest więc nie tylko narzędziem służącym do przemieszczania się — jest funkcjoznakiem, swego rodzaju reprezentacją jego właściciela, a zarazem społeczeństwa, którego jest on członkiem. Jest materializacją i obiektywizacją funkcjonujących w danym społeczeństwie systemów wartości, a jego używa- 
nie tworzy społeczną i kulturową rzeczywistość. Pozwala jednostkom wyrażać siebie w sposób (w założeniu) zrozumiały dla innych, może też wyrażać przynależność do określonej grupy czy subkultury (Krajewski 2005, s. 8), a jego marka czy model mogą wskazywać na styl życia czy cechy osobowości właściciela. Pamiętać jednak należy, że częstokroć symbol - jakim niewątpliwie jest samochód - wiąże się ze znaczeniami złożonymi i nieoczywistymi, może też zastępować coś, co w ogóle nie istnieje, albo wskazywać na jakiś głębszy poziom rzeczywistości (Hałas 2007, s. 18).

Abstrahując od funkcji mobilności, chciałbym zastanowić się nad pozostałymi cechami samochodu. Jak już wspomniałem, może on być symbolicznym atrybutem pozycji społecznej jego właściciela. Jako przedmiot widzialny dla innych umiejscawia właściciela w przestrzeni społecznej. Pozwala mu być kimś podobnym do pozostałych (przecież wszyscy mają samochód) i jednocześnie daje możliwość odróżnienia się od otoczenia społecznego (ale nie taki jak ja) (Pietrowicz 2004, s. 69-70). Atrakcyjność samochodu jako symbolu statusu zwiększa jego wyjątkowość, związana przeważnie z marką, modelem czy ceną. W popularnym dzienniku czytamy: „przyjęło się, że porsche to nie tylko prędkość; to także pieniądze i prestiż — słowem powodzenie; a dla wielu klientów to wystarczająca rekomendacja” ${ }^{1 ;}$, ,...] poza tym obydwa pojazdy nadają się świetnie do lansowania; siedząc za kierownicą tych aut, bardzo szybko stajesz się znaną osobą" ${ }^{2}$. Samochód zatem jako symbol statusu może pełnić dość istotną rolę $\mathrm{w}$ konstruowaniu tożsamości jego właściciela. „To, co kupujemy [zatem posiadamy — przyp. M. F.], także wpływa na to, kim się stajemy. [...] im więcej mamy, tym bardziej czujemy się silni, pewni siebie i istotni społecznie" (zob. Pietrowicz 2004, s. 70).

Można też dostrzec dążenie do uczynienia swego samochodu niepowtarzalnym, charakterystycznym, jedynym w swoim rodzaju. Pragnienie wyrażania siebie poprzez samochód znajduje wyraz zarówno w drobnych naklejkach czy innego rodzaju dodatkach, jak i w kompleksowych przeróbkach i modyfikacjach wyglądu pojazdu i jego mechanizmów wewnętrznych. Przyozdabianie, doposażenie czy wszelkie przejawy subkultury tuningowej to działania skierowane na zewnątrz - ekspresywne wykorzystanie pojazdów do swoistej indywidualizacji, podkreślenia pewnych własnych cech, zakomunikowania czegoś pozostałym.

Samochód wpływa też niewątpliwie na sposób aktywności kierujących w przestrzeni publicznej. Są oni w pewien sposób odizolowani od bezpośrednich interakcji z innymi. Tworzą swój odrębny świat charakterystycznych symboli, znaczeń, praktyk, zwyczajów i interakcji. Zamknięci w częściowo tylko przejrzystych, stalowo-szklanych „puszkach”, ulokowani są między przestrze-

\footnotetext{
1 A. Włodarski, La bella machina, „Gazeta Wyborcza”, dodatek „Wysokie Obroty”, 7 sierpnia 2008.

2 S. Mroczek, Banzai!, „Gazeta Wyborcza”, dodatek „Wysokie Obroty”, 4 września 2008.
} 
nią prywatną a publiczną. $Z$ jednej strony mogą być obserwowani przez innych i sami mogą obserwować, $z$ drugiej zaś zamknięci są w obiekcie, który umożliwia obserwację tylko części ich ciała, to jest głowy, części tułowia i rąk, co wyłącza ich czy wręcz izoluje od otaczającego środowiska zewnętrznego. Auto jest więc przestrzenią półprywatną (czy też półpubliczną) przemieszczającą się $\mathrm{w}$ przestrzeni o charakterze publicznym. Owa mieszanka, w połączeniu z hybrydą, jaką jest zestawienie człowieka, maszyny, drogi i infrastruktury, tworzy przestrzeń powstawania nie spotykanych w innych kontekstach relacji i interakcji. Choćby tylko wzrok, który pozwala przez patrzenie tworzyć naturalne związki i bezpośrednie, najczystsze formy interakcji (zob. Urry 2008, s. 416-417), musi zostać odpowiednio zmodyfikowany, gdyż kierujący postrzegają nie ludzi, ale właśnie hybrydy. Patrząc na to, co dzieje się dookoła, kierujący nie widzi ludzi i ich twarzy — lecz samochody, a dopiero w jego świadomości, czy wręcz podświadomości, tworzy się wizja, w której sterowane są one przez człowieka. Może też dostrzegać samochody oraz fragmenty ich kierowców - czasem tył głowy, czasem profil, nieczęsto zaś mimikę twarzy czy spojrzenie. Trudno zatem o wzajemność, o zaangażowanie, trudno uzyskać charakterystyczne dla interakcji twarzą $\mathrm{w}$ twarz bogactwo strumienia informacji, także informacji zwrotnych (zob. Goffman 2008, s. 18-20). Jest to więc bardzo specyficzny rodzaj ws półobecności - człowiek ma poczucie, że znajduje się wystarczająco blisko, by inni mogli obserwować jego aktywność, on także może obserwować innych, bliskość ta zarazem pozwala dostrzec innym, iż jest świadom ich obserwacji (Goffman 2008, s. 21), która jednak jest częściowa, niepełna, fragmentaryczna. Obserwować można bardziej efekt działania jednostki, to jest sposób poruszania się kierowanego przez nią samochodu, niż ją samą. Zdarzają się tylko krótkie chwile, kiedy pojazdy jadąc wolno wymijają się lub stają obok siebie i kiedy można wymienić się spojrzeniami czy dostrzec wyraz twarzy. Mało tu miejsca nawet na Goffmanowską „uprzejmą nieuwagę", gdyż aby spuścić wzrok czy odwrócić spojrzenie, trzeba najpierw to spojrzenie $z$ kimś wymienić.

Zachwianiu czy reorganizacji ulega również cała pozostała część sfery komunikacji niewerbalnej. Takie sygnały jak wygląd, postawa, ruchy czy przyjmowane pozycje, a także gesty i mimika twarzy mimo bezpośredniej bliskości jednostek są w znacznym stopniu ograniczone. Samochód staje się mobilną osłoną, która zakrywa siedzącą w nim jednostkę, a zarazem nie pozwala jej na lustrację znajdujących się dookoła innych. Jak dowodzi Robert E. Park: „W ludzkim społeczeństwie każde działanie każdego człowieka staje się gestem, ponieważ to, co robimy, jest zawsze oznaką tego, co chcieliśmy zrobić. W rezultacie, człowiek w społeczeństwie prowadzi mniej lub bardziej publiczną egzystencję, ponieważ wszystkie jego działania są oczekiwane, kontrolowane, ograniczane lub modyfikowane przez gesty i intencje bliźnich. Właśnie w ramach tego konfliktu, w którym każdy człowiek żyje w mniejszym lub większym stopniu, w umyśle wszystkich pozostałych, ludzka natura i sam człowiek nabie- 
rają swoich najbardziej charakterystycznych i najbardziej ludzkich cech" (cyt. za: Goffman 2008, s. 20). Jednak działania jednostki podczas kierowania samochodem są, czy też mogą być, kontrolowane i modyfikowane przez pozostałych w sposób bardzo ograniczony. Prawie wcale nie ma możliwości przekazania komunikatu słownego - okrzyki wznoszone przez kierujących rzadko docierają do adresatów. Pozostaje więc przestrzeń niewerbalna, której elementy z natury są mniej czytelne, trudniej rozumiane i często błędnie interpretowane. Właściwe odczytanie gestów i intencji innych jest bardzo utrudnione także $z$ uwagi na to, że kierowca jest otoczony różnymi przyrządami, które stale musi obserwować i obsługiwać. Ruch drogowy, ciągła i bardzo szybka zmiana sytuacji, konieczność stałego definiowania i interpretowania szybko następujących po sobie nowych zdarzeń oraz konieczność natychmiastowego dostosowania się do nowych warunków pozostawiają kierującym niewiele czasu i możliwości dokonywania obserwacji innych ludzi, a tym bardziej detali ich aktywności, jak mimika twarzy czy drobny gest ręki. Świat widziany $z$ samochodu to przede wszystkim, poza infrastrukturą drogową i światem w ogóle, rzeczywistość innych samochodów. Ponadto $\mathrm{w}$ małej przestrzeni auta kierowca niemal się nie porusza - fotel otulający szczelnie uda, tułów i ramiona, a także konieczność przypięcia się do niego pasami bezpieczeństwa ograniczają ruchy kierowcy do niezbędnego minimum. Krótkie, efemeryczne wymiany spojrzeń czy prawie niezauważalne gesty nikną w natłoku innych bodźców, którym poddawany jest kierujący. Jakkolwiek samochód można traktować jak rozszerzenie zmysłów i kierowca może wcielić się $\mathrm{w}$ jego kształt, obrys i czuć związek z tym, co dzieje się poza jego metaliczną powłoką (Urry 2008, s. 420), to chodzi raczej o stosunek do innych samochodów czy hybryd.

Kierowanie samochodem i uczestnictwo w ruchu drogowym wymaga przy tym dużych umiejętności, nie tylko technicznych, ale i interakcyjnych. Człowiek $z$ jednej strony brata się $z$ maszyną i wciela $w$ nią, ale $z$ drugiej to $w$ końcu on nią steruje (przynajmniej dotychczas, choć coraz więcej dodatkowych urządzeń pomaga mu $\mathrm{w}$ tym $\mathrm{w}$ coraz większym stopniu, często wręcz przejmuje część obowiązków kierowcy). Mijające się w ruchu ulicznym samochody są więc tylko „obudowami”, w których umieszczony jest człowiek. I ten człowiek w zdecydowanej większości przypadków ma wpływ na to, jak owa obudowa się „zachowuje”. Tym samym w odniesieniu do zachowań społecznych kierowców samochodów zastosowanie mają wszelkie ustalone przez psychologię, psychologię społeczną i wreszcie socjologię prawidłowości, reguły i uwarunkowania działań ludzkich. Pewnie nieco zmodyfikowane i dostosowane do hybrydycznego stosunku człowieka i maszyny, ale jak najbardziej na miejscu. W końcu to od działań jednostki oraz działań otoczenia zależy to, czy przemieszczanie się samochodem przebiega sprawnie i bezpiecznie. Kierowca nie może polegać tylko na sobie, ale musi współdziałać z pozostałymi, starać się przewidywać ich działania, a ponieważ nigdy nie da się antycypować działań innych precyzyjnie i całkowicie właściwie, niezbędna jest pewna doza zaufania. Świat społeczny to 
ludzie i ich działania, co razem wzięte tworzy środowisko życia każdego człowieka (Sztompka 2007, s. 62-63). To od człowieka, a nie od samochodu, zależy, czy właściwie zostanie oceniona, zdefiniowania i zinterpretowana sytuacja i to człowiek podejmie decyzję, jak należy na nią zareagować. Gra toczy się zarówno wokół umiejętności kierowania, ale i wokół umiejętności kontrolowania emocji i radzenia sobie w sytuacjach stresowych, umiejętności szybkiego reagowania i podejmowania decyzji, wreszcie wokół umiejętności odczytywania intencji i interpretacji zachowania innych kierowców.

Uczestnicy ruchu drogowego, poza nielicznymi momentami nocnej jazdy boczną drogą, pozostają w ciągłej i permanentnej interakcji z innymi. Owe interakcje często zbliżone są do zdefiniowanej przez Ervinga Goffmana interakcji niezogniskowanej, czyli komunikacji, która zachodzi gdy człowiek zbiera informacje o współobecnej osobie, zerkając na nią przelotnie oraz modyfikuje swoje zachowanie z powodu znajdowania się pod obserwacją (Goffman 2008, s. 29). Działania kierowcy i wszystkich innych dookoła są społecznie usytuowane, ponieważ dzieją się w bezpośredniej obecności innych (Goffman 2006, s. 293). Być może obecność innych ma tu bardziej złożony charakter niż w warunkach bezpośredniego spotkania, ale niewątpliwie jest faktem. Ludzie-kierowcy identyfikują i kategoryzują się wzajemnie, a także typizują sytuacje, w których się znaleźli, jednak na podstawie innych niż poza samochodem przesłanek. Ponieważ raczej nie widzą siebie wzajemnie, lecz jedynie samochody i efekty działań innych uczestników ruchu, czyli to, jak owe samochody się poruszają, to na ich obserwacji muszą zasadzać swoje interpretacje. Jednocześnie ponieważ wiele podobnych sytuacji i zjawisk już przeżyli, uruchamiają odpowiednie schematy postępowania, osadzone $\mathrm{w}$ podświadomości, czyli reagują i działają poprzez nawyki.

Samochody, wraz z całym spektrum charakterystycznych zachowań związanych z ich użytkowaniem, są więc niezwykle istotnymi, często wieloznacznymi i wielowymiarowymi, kanałami komunikacji z otoczeniem. Wyróżniłbym trzy rodzaje komunikacji w ramach „kultury automobilności”: (1) z samochodu, (2) samochodem, oraz (3) samochodem $z$ samochodu.

W ramach systemu komunikacji nazywanego przeze mnie „z samochodu” możemy wyodrębnić wiele znaków i komunikatów, które nadają do siebie kierujący pojazdami. Począwszy od zwerbalizowanych okrzyków czy w inny sposób wypowiedzianych słów, przez niewerbalne miny, spojrzenia, gesty, kiwnięcia, do używania klaksonu i mrugnięcia światłami.

Marka czy model samochodu dla uczestników ruchu drogowego mogą służyć jako wyznacznik statusu materialnego jego właściciela, a tym samym lokować go na odpowiednim szczeblu hierarchii społecznej i w konsekwencji wywoływać określone reakcje. Jednocześnie dla właściciela charakterystyczne doposażenie auta może być sposobem radzenia sobie z pragnieniem wyrażania i uzewnętrzniania siebie. Samochód może komunikować, kim dana osoba jest, jak się zachowa, czego można się po niej spodziewać i gdzie umieszczać 
ją na drabinie statusów (Pietrowicz 2004, s. 71). Ten sposób przekazywania informacji nazwałbym „komunikacją samochodem”3.

Bardzo płynną, nieostrą i trudną do analizowania formą komunikacji, którą można nazwać „komunikacją samochodem z samochodu”, może być styl jazdy. Można go traktować $z$ jednej strony jako uzewnętrznienie pewnych cech oraz umiejętności kierującego, z drugiej zaś jako demonstrację sposobu postrzegania siebie i innych uczestników ruchu drogowego. Przeniesienie swoich emocji na drogę oraz charakter jazdy mogą komunikować pozostałym, czy kierujący jest agresywny, czy spokojny, czy jest dobrym kierowca, czy nie bardzo, czy spieszy się dokądś, czy też dysponuje nadwyżką czasu, wreszcie czy kieruje nim zdrowy rozsądek, czy też traktuje ulice jako pole bitwy, a wszystkich pozostałych uczestników ruchu jak przeciwników albo wręcz wrogów.

W tygodniku „Auto Świat” na podstawie postrzeganych charakterystycznych elementów stylu jazdy wyodrębniono pięć profili psychologicznych kierowców. Kierujący, którzy jadąc starają się narzucać swoją wolę innym, są agresywni i egoistyczni, nazwani zostali mad maxami. Tacy, którzy nie tolerują najmniejszych błędów $\mathrm{u}$ innych i przesadnie na nie reagują, próbując jednocześnie „uczyć” innych, jak należy jeździć, to w y ch ow a w cy. Niektórzy kierujący udają, że nie potrafią kierować lub nie znają okolicy, by zatuszować swe prawdziwe zamiary ominięcia wszelkich przeszkód, które stanęły na ich drodze. Nazwano ich słodki mi idi o tka mi. Są też tacy, którzy traktują swój samochód jak twierdzę izolującą ich od nieprzyjaznego świata zewnętrznego, są w tym nieprzewidywalni i mogą być zarówno defensywni, jak i agresywni, a określenie do nich pasujące to odreagowujący lęki. I wreszcie ostatnia grupa typologii „Auto Świata” to zdroworozsądkowcy unikający konfliktów i starający się przede wszystkim bezpiecznie dotrzeć do celu - to a sertywni $\mathrm{i}^{4}$. Jak sugeruje tytuł artykułu opublikowanego w „Wysokich Obrotach”: „wsiądź do auta, a powiem ci kim jesteś" ${ }^{5}$. Styl jazdy może być więc bardzo ważnym i bogatym w treści komunikatem. Jednak odbiór i właściwa interpretacja tej wiadomości jest $\mathrm{z}$ reguły zadaniem trudnym i wymaga sporych kompetencji.

W tym miejscu warto przywołać tezę stawianą przez Elżbietę Hałas, która twierdzi, iż komunikacja to między innymi podzielane znaczenia, które wyrastają z działania grupy, której członkowie są zdolni do uczestnictwa w różnych skoordynowanych działaniach, ponieważ podzielają wspólną terminologię (Hałas 2007, s. 39-40). Oznacza to, iż aby nadawca i odbiorca rozumieli się, by nadany komunikat był właściwie zinterpretowany, muszą współegzystować

\footnotetext{
${ }^{3}$ Kwestią do rozważenia pozostaje to, w jakim stopniu komunikat w ten sposób nadawany jest odbierany i rozumiany przez pozostałych. Może jest to szyfr rozumiany jedynie przez nielicznych.

4 „Auto Świat”, 12 stycznia 2009.

${ }^{5}$ Wsiądź do auta, a powiem ci kim jesteś. Z Andrzejem Markowskim, wiceprzewodniczącym Stowarzyszenia Psychologów Transportu, rozmawia Filip Wasilewski, „Gazeta Wyborcza”, dodatek „Wysokie Obroty”, 8 stycznia 2004.
} 
w przestrzeni tych samych symboli i w ten sam sposób je rozkodowywać. Czy tak się dzieje?

\section{KODY KOMUNIKACJI MIĘDZY KIEROWCAMI I ICH INTERPRETACJE}

Najpowszechniejsze - ale i najbardziej wieloznaczne - sposoby przekazywania informacji między kierowcami to przede wszystkim gesty rękoma, sygnały o mniejszych możliwościach interpretacji to krótkie mrugnięcia światłami drogowymi, jeszcze bardziej jednoznaczne jest chwilowe włączenie świateł awaryjnych, najmniej wątpliwości interpretacyjnych budzą sygnały dźwiękowe nadawane klaksonem.

Gesty wykonywane rękoma mogą być zarówno pozdrowieniem, przeproszeniem, podziękowaniem czy sygnałem udzielenia pierwszeństwa, ogólnym ostrzeżeniem o zagrożeniu na drodze, poinformowaniem o braku świateł czy znajdującym się blisko patrolu policji drogowej, jak i wyrazem dezaprobaty dla zachowania innego uczestnika ruchu, groźbą czy oznaką agresji. Na przykład uniesiona do góry otwarta dłoń może być wyrazem podziękowania, przeproszenia oraz pozdrowienia, wysunięta przed siebie otwarta dłoń to często wyraz udzielenia pierwszeństwa przejazdu. Z kolei pukanie palcem wskazującym w czoło może wyrażać dezaprobatę dla zachowania innego kierowcy, a wymachiwanie dłonią zaciśniętą $\mathrm{w}$ pięść symbolizuje groźbę i agresję. Trzeba pamiętać, że pojawić się mogą duże trudności ze wskazaniem schematu interpretacji poszczególnych gestów - jako kod rozszyfrowujący służy przede wszystkim kontekst sytuacji, w jakiej dany gest się pojawia. Ô kontekst jest zresztą głównym kluczem interpretacji wszelkich sygnałów.

Interpretuję $w$ zależności od tego, co nastapiło wcześniej, po jakiej sytuacji nastapił dany sygnał albo przed jaka sytuacja, czyli wiem, że jeżeli na przykład ja kogoś wpuścitem $i$ on mi daje awaryjnymi sygnat [...] albo jak podniesie rękę, to też znaczy, że mi podziękuje, a nie, że chce się przywitać. I to też zależy od kontekstu, to bytoby na przykład coś, co by mnie mogło zdziwić, jakbym na przykład jechat sobie w jedna strone, kierowca jedzie $z$ przeciwka $i$ by nagle podnióst rękę, a ja go nie znam, to by mnie zdziwito, bo bym zglupiat, bo nie wiem, co to znaczy, $w$ takim kontekście zupetnie się nie zdarza. To jest to, że musi być kontekst [...] odnoszę do kontekstu automatycznie, odruchowo, wtaściwie czlowiek się nad tym nie zastanawia ${ }^{6}$.

W drogowych relacjach między kierowcami obserwuje się również wulgarny gest fuck off, polegający na pokazaniu uniesionej dłoni z wysuniętym środkowym palcem. Jest to gest interpretowany jednoznacznie jako, delikatnie mówiąc, nakaz odczepienia się od nadawcy, uznawany za bardzo obraźliwy, brutalny i wulgarny.

${ }^{6}$ Ta wypowiedź respondenta, a także inne dalej cytowane, wyróżnione kursywą, pochodzi z badania przeprowadzonego przeze mnie w grupie czterdziestu osób techniką wywiadu pogłębionego wiosną $2009 \mathrm{r}$. 
Gesty rękoma są często wykorzystywaną formą komunikacji między kierowcami, dają duże możliwości przekazywania informacji, a co za tym idzie wielość ewentualnych interpretacji. Są wyrazem emocji, swoistym emblematem postawy oraz przekaźnikiem informacji praktycznych. W sytuacjach kontaktów bezpośrednich są uzupełnieniem kontaktu językowego, w samochodzie $z$ reguły występują samoistnie w miejscu ich słownych odpowiedników. Owa wielość możliwości ich interpretacji może powodować częste niezrozumienia czy błędne rozszyfrowania.

Mniej wieloznaczną formą przekazania informacji jest krótkie włączenie świateł drogowych, czyli mrugnięcie tzw. długimi. Jest to sygnał najczęściej oznaczający ostrzeżenie przed kontrolą policyjną, ku której zbliża się odbiorca, lub zwrócenie uwagi na brak świateł dziennych u odbiorcy. Niekiedy służy zasygnalizowaniu jakiegoś problemu lub udzieleniu pierwszeństwa przejazdu, może też zostać zinterpretowane jako pozdrowienie. Interpretacja tego znaku, czyli reakcja na jego dostrzeżenie, często wymaga wielu czynności i potwierdzeń.

To zależy od sytuacji, bo jak na przykład ktoś mi mrugnie dtugimi, to najpierw patrze czy mam wtaczone światła, jeśli mam wtaczone światta, to mogę sie spodziewać, że może albo się coś innego stać, na przykład cokolwiek - no koto mi się rusza czy tam dymie spod maski, a jeśli nie, ogólny rzut oka, no to $w$ takim razie gdzieś stoja jakieś miśki ${ }^{7}$, gdzieś się tam czaja w krzakach.

Sygnał ów wywołuje pewien zestaw działań ze strony odbiorcy, począwszy od upewnienia się, co do jazdy w zgodzie z przepisami kodeksu drogowego, poprzez dokonanie obserwacji stanu samochodu, na wzmożeniu czujności i spowolnieniu jazdy kończąc. Jest to więc znak ostrzegawczy uruchamiający z jednej strony pewnego rodzaju działania przygotowawcze czy obronne związane ze zbliżającym się możliwym niebezpieczeństwem, z drugiej zaś przegląd stanu faktycznego i ewentualne korekty działania.

Kolejnym komunikatem, dającym jeszcze mniej możliwości interpretacji, jest chwilowe włączenie świateł awaryjnych. Jego dwa podstawowe znaczenia to podziękowanie oraz ostrzeżenie przed jakąś niebezpieczną sytuacją drogową, którą nadający już zauważył, a poruszający się za nim odbiorca najprawdopodobniej jeszcze nie. Interpretacja zasadza się tu na przekonaniu, że jeżeli nadawca nie dziękuje, bo nie zaistniała odpowiednia sytuacja, to ostrzega przed jakimś niebezpieczeństwem.

W komunikacji drogowej często używa się też sygnału dźwiękowego, tzw. klaksonu. Sygnał ten stanowi przede wszystkim ostrzeżenie, formę krzyku ostrzegawczego bądź ponaglenie. Jego zdefiniowanie zależy od sytuacji, w jakiej znajdują się nadawca i odbiorca, przy czym problemem może być to, iż sygnał ten jest dostępny dla wszystkich znajdujących się w pobliżu uczestników ruchu.

\footnotetext{
${ }^{7}$ Miśki — określenie policji powszechne wśród użytkowników CB-radia.
} 
Klakson jest przez kierowców używany $w$ celach ostrzegawczych - to wiem i styszę. Na przykład miała miejsce taka sytuacja drogowa, że stałam na równoległym pasie z innym kierowca, na światłach, $i$ zrobito się zielone, a to byt taki wysoki jakiś minivan $i$ ten kierowca zacząt trąbić nagle i nie ruszyt, tylko zaczą trąić. Więc zaniepokoitam sie $i$ również nie ruszyłam, stałam $i$ patrzyłam, co sie dzieje, $i$ się okazało, $\dot{z} e$ on mnie ostrzegat, żebym nie jechała, bo z lewej strony nadciagat autobus, który musiat przejechać na czerwonym świetle, skoro my już mieliśmy zielone. I po prostu gdybym ruszyta, to by mnie rozjechat. I to, $\dot{z} e$ on trabit, a ja nie widziałam tego kierowcy, bo byt dużo wyżej niż $j a$, ale trabit $i$ nie jechat, uratowato mnie tak naprawdę przed poważna kraksą.

Jakże łatwo więc może dojść do niezrozumienia między kierowcami i błędnej interpretacji sygnału. $Z$ jednej strony podczas zmiany świateł na zielone klakson ma ponaglić ospałego kierowcę, by rozpoczął jazdę, z drugiej zaś może być sygnałem ostrzegawczym wzywającym do zachowania zupełnie odwrotnego, a więc stania w miejscu. Stały schemat interpretacji: stoję — ponaglenie, jadę - ostrzeżenie, może zatem być zawodny, a cytowaną respondentkę uratowała zapewne niejednoznaczność sytuacji — zidentyfikowała jako nadawcę sygnału kierowcę pojazdu, który znajdował się obok, a nie za nią, a ponadto nie ruszał mimo zielonego światła. Uproszczenia myślowe, pomagające zrozumieć wieloznaczną rzeczywistość społeczną i schematy interpretacji otrzymywanych informacji, niekiedy zderzają się z niejednoznacznością. Wtedy działanie jednostki stać się musi bardziej refleksyjne i świadome, inne niż podpowiada narzucający się schemat interpretacyjny (zob. Aronson, Wilson, Akert 1997, s. 128-130).

Ponadto istnieje, oczywiście, wiele innych możliwości wzajemnego przekazania informacji. Może to być krzyk - słyszany przeważnie jedynie przez nadawcę w zamkniętym samochodzie - jako wyraz zdenerwowania czy oburzenia związanego $z$ zachowaniem innego kierującego. Jego uzupełnieniem, ale i znakiem występującym samoistnie, jest mimika twarzy, wyrażająca na przykład gniew czy zdziwienie. W trakcie błyskawicznych wzajemnych obserwacji kierowcy nie mają jednak zbyt wielu możliwości dostrzeżenia wyrazu twarzy. Ten jeden $z$ podstawowych kanałów komunikacji niewerbalnej w trakcie jazdy samochodem używany jest zatem w dość ograniczonym zakresie.

Innymi metodami komunikacji są bezpośrednia rozmowa oraz styl jazdy, który omówię w dalszej części, gdyż stanowi odrębne zagadnienie.

Jeśli chodzi o podstawowy werbalny sposób komunikacji międzyludzkiej, czyli rozmowę, to jest ona w czasie jazdy bardzo utrudniona. Samochód izoluje ludzi od siebie, a ponadto stale się przemieszcza w ulicznym hałasie. Zdarza się jednak, że w korku kierujący opuszczają szyby i przekazują sobie wzajemnie informacje. Rozmowy takie to jednak raczej jednostronne przekazywanie uwag na temat zachowania w czasie jazdy innego uczestnika. W ruchu drogowym nie ma czasu i możliwości na wielowątkowe dysputy, chyba że kierujący zjadą na parking, ale tym samym „wyjeżdżają” również poza zakres tych rozważań. 
Niezmiernie ważna i ciekawa jest kwestia ogólnych schematów interpretacji omówionych znaków i symboli. Od nich przecież zależy efektywność i skuteczność komunikacji w ogóle, a tym samym komunikacji między kierowcami.

Ponieważ nie ma kodeksu sygnatów $i$ znaków, to tak naprawdę każdy odbiera po swojemu, a interpretacja zależy pewnie od tego, w jaki sposób ja nadaję te same sygnaty, dla mnie znak świattami to jest „puszczam cię stary, jedź sobie do przodu”, a dla faceta, który rabnat $w$ moja ciotkę, to było „uwaga jadę” [...], a więc ja będę rozumiała znaki tak, jak ja je daje.

Jakie zatem są owe schematy i od czego zależy właściwe rozkodowanie informacji, jaką kierujący otrzymują od siebie wzajemnie?

Działają tu zapewne reguły teorii społecznego uczenia się. Jeden z mechanizmów opisywanych przez tę teorię polega na obserwacji innych i przyswajaniu tego, co przyniosło pożądane konsekwencje, a unikaniu tego, z czym wiążą się kłopoty. Ludzie obserwują, co robią inni, oraz konsekwencje tych działań, a potem starają się owe zachowania naśladować. Działania o konsekwencjach dobrych i pożądanych są powtarzane, aż w końcu stają się wyuczonym nawykiem (Zimbardo, Leippe 2004, s. 67-68). Wzmacniający wpływ wywiera tu porzeba poprawności, czyli oceny własnych postaw i potwierdzenia, że są prawidłowe, czemu służy obserwacja i powtarzanie zachowań innych (Zimbardo, Leippe 2004, s. 80). Jednocześnie działa reguła wzajemności, która nakazuje pomóc tym, którzy nam pomogli (Zimbardo, Leippe 2004, s. 103), a z braku możliwości odwdzięczenia się konkretnej osobie ową wzajemność kieruje się wobec kogoś innego, oczekując od innych tego samego i licząc ogólnie na pozytywne konsekwencje komunikacji wzajemnej.

Istotny jest proces wtórnej socjalizacji wprowadzający jednostkę $\mathrm{w}$ nowy sektor obiektywnego świata społecznego - świata kierowców. W toku tego procesu następuje identyfikacja $z$ rolą społeczną kierowcy, która dostarcza wzorców postępowania w rozmaitych sytuacjach i determinuje pewne postawy. Proces ten rzadko jest świadomy czy oparty na refleksji — dyscyplina roli kształtuje zarówno działania, jak i działającego, a jednostka staje się tym, kogo odgrywa (Berger 2000, s. 119-120).

$\mathrm{Na}$ warunki właściwej interpretacji informacji w ruchu drogowym składa się też konieczność odniesienia danego sygnału czy znaku do określonej sytuacji.

Jest to coś, co sie nieodtacznie taczy $i$ jest związane $z$ tym, nie mam podstaw, żeby to inaczej interpretować. No jak ktoś mi puka w czoło, bo mu zajechatem droge, no to na pewno mnie nie pozdrawia [...] jeżeli czegoś nie zrozumiem — nie wyjdę, żeby spytać.

Schematy interpretacji komunikatów krążących wśród kierowców samochodów mogą być dość rozbudowane i niejednoznaczne, jednak z uwagi na bardzo krótki czas, jaki kierowcy mają do dyspozycji, a także brak możliwości dopytania czy doprecyzowania wiadomości, zrozumiałe jest, iż w stałym i częstym użyciu pozostaje tylko kilka sygnałów, te, których interpretacje na- 
rzucają się uczestnikom ruchu i nie wymagają świadomego namysłu. Choć i tak o pomyłkę nietrudno.

Specyficznym sposobem komunikacji jest (czy też może być) charakterystyczne doznakowanie samochodu. Zawierać ono może zarówno informacje o właścicielu, jego postawach, stylu życia czy światopoglądzie, jak i dane praktyczne związane z przeznaczeniem pojazdu bądź charakterem jego użytkowania.

Najbardziej charakterystyczne są przeróbki mające wpływ na wygląd, wykonywane przez właściciela bądź wyspecjalizowane warsztaty. Jest to zapewne najbardziej zauważalny znak, często jednak łączony z mającym pejoratywny wydźwięk określeniem — wiejski tuning.

Jeśli mówimy o doznakowaniu, to widać wiejski tuning pod nazwa megaspoiler do samochodu, który nie przekracza stu na godzinę.

Jaki jest schemat interpretacji zjawiska tuningu? $\mathrm{Z}$ jednej strony jest to oznaka chęci wyróżnienia się wśród tłumu i potrzeby samodowartościowania, jaką odczuwa kierowca, z drugiej zaś sposób na zaimponowanie innym („szpan” czy „lans”).

Mam taka wypasiona furę, nie? No wiadomo - chca się wyróżniać z tłumu, prawda, zaimponować chtopakom $w$ swoim wieku albo nie wiem - wyrwać laskę.

Istotne jest, by przekaz wyrażony w przeróbce samochodu nie był obojętny estetycznie dla odbiorcy, a także to, że owe przeróbki wpisują się $\mathrm{w}$ pewien stereotyp tego, jak przeciętny kierowca postrzega pojazd odbiegający od zakodowanego standardu. Każdej bowiem interpretacji towarzyszy jakiś kontekst, a odbiorca interpretuje przekaz zgodnie $z$ własnymi skojarzeniami, doświadczeniami czy stereotypami (Golka 2008, s. 53-56). Przerabianie samochodów prawdopodobnie ma wywołać postawy raczej pozytywne, tymczasem nierzadko prowokuje raczej negatywne. Być może jednak właściciele tuningowanych pojazdów dążą do uzyskania pewnej identyfikacji, utożsamienia się z jakąś grupą, dla niektórych zapewne grupą odniesienia, i zamanifestowania swojej przynależności do pewnej subkultury kierowców, obojętny jest im natomiast sposób interpretacji tego komunikatu przez ogół kierowców.

Zupełnie innego rodzaju komunikatem może być styl ja zdy, czyli indywidualny, charakterystyczny dla danego kierowcy sposób kierowania samochodem. Polega on na określonej dynamice jazdy, jej płynności oraz wykazywaniu stopnia uprzejmości wobec innych kierowców. Kierowcy dość często wiele o sobie „opowiadają" swym sposobem jazdy i wiele $z$ owych „opowieści” jest uważnie „słuchanych” przez innych uczestników ruchu.

Wydaje mi się, że styl jazdy wynika $z$ charakteru osoby, no to tak jakby w sumie, jasne chyba, $z$ charakteru osoby, która siedzi za tym kótkiem. Sa różne rodzaje w zależności od, tak jak mówię, od tego, kto siedzi. Widać, że na przykład osoba, która niedawno zdata prawo jazdy, inaczej się zachowuje niż osoba, która już tam jeździ jakiś czas, widać 
to [...] z samej sprawności jazdy, czyli jak ta osoba sie, powiedzmy, zachowuje za tym kótkiem.

Jedziesz za kimś, to widzisz, czy kierowca jedzie pewnie, czy na przykład, nie wiem, przyspiesza, wyprzedza kogoś, czy co chwile zmienia pas i na swój $z$ powrotem $i$ na przykład zwalnia. To sa dla mnie tacy kierowcy, tacy troche niepewni $i$ nie za bardzo wiedzacy, jak chca jechać - no generalnie styl jazdy.

Styl jazdy jest często nieuświadomionym komunikatem nadawanym przez kierowcę, a odbieranym przez obserwujących go innych użytkowników drogi, zawiera on sporą dawkę informacji o nadawcy. Silna tendencja do postrzegania zachowania jako odzwierciedlenia dyspozycji czy przekonań (Aronson, Wilson, Akert 1997, s. 196) determinuje zapewne wyobrażenie o kierowcy zgodne $z$ jego stylem jazdy - flegmatyczny, niezdecydowany, elastyczny, umiarkowany czy agresywny. Ludzie przy tym widząc, czy raczej świadomie postrzegając zachowanie innego kierowcy — jego sposób jazdy — budują sobie jego wyobrażenie oraz oceniają go w odniesieniu do własnego systemu wartości (Golka 2008, s. 52-58). Jednocześnie ze względu na selektywny odbiór bodźców uwypuklają się cechy graniczne, te najbardziej wyraziste, najbardziej jaskrawe, by nie rzec skrajne, co może powodować trudności w zauważeniu i interpretacyjnym odebraniu kierowcy o stylu jazdy nierzucającym się $\mathrm{w}$ oczy - [...] ale zwykłego kierowce, to ja nie umiem scharakteryzować [...], ja go w ogóle nie biorę pod uwage, bo ja go nie zauważam.

Styl jazdy może być bardzo ważnym elementem komunikacji, dostarczającym wiedzy i informacji nie tyle o tym, co dzieje się na drodze, ile o kierowcy - jego postawach i dyspozycjach. Jest to jednak wiedza, która pozostaje poza świadomością odbiorców, będąca elementem ich habitusu (zob. Kaufmann 2004, s. 132).

Obok stylu jazdy, który rozumiem jako indywidualny, charakterystyczny dla danego kierowcy sposób kierowania samochodem w różnych sytuacjach drogowych, wyodrębniłbym sposób jazdy - całkowicie ulotny, efemeryczny, charakterystyczny jedynie dla danej chwili i silnie uzależniony od okoliczności na drodze. Sposób jazdy - obok szeroko rozumianego samochodu (maska, gabaryty, doznakowanie) oraz osoby kierowcy — jest ważnym elementem identyfikacji wzajemnej kierowców, którzy dokonują oceny innego kierującego pojazdem na podstawie obserwacji tego, jak prowadzi samochód. Stosowna interpretacja często wpływa na postawę obserwatora wobec obserwowanego kierowcy.

Jak widzę, że jest jakiś agresywny kierowca, na przyktad widze w lusterku, że ktoś tam gdzieś śmiga, to zwolnię i przepuszcze go, żeby sobie pojechat i niech sobie jedzie dalej, nie. To to sa takie reakcje.

Wyłania się zatem schemat wzajemnego postrzegania się kierowców wskaźnikiem i komunikatem determinującym identyfikację jest sposób jazdy, 
a możliwą reakcją na ów komunikat zmiana neutralnej postawy odbiorcy wobec nadawcy, a także korekta działania.

Istotną rolę w identyfkacji wzajemnej odgrywa s a m o chód jako przedmiot oraz jako funkcjoznak.

Pierwsze pod uwage co biore to, czym jedzie, to od razu wiem mniej więcej czy to będzie osoba młoda czy starsza, może nie zawsze się to potwierdza, ale generalnie model samochodu. Sposób jazdy określa też, kto może kierować tym samochodem.

Samochód jawi się jako swoisty wskaźnik identyfikujący kierowcę i pozwalający przewidywać innym jego działania. W tych mikroobserwacjach kierowcy skupiają się na pewnych cechach charakterystycznych danego pojazdu oraz dokonują na ich podstawie interpretacji na potrzeby danej chwili — zakładają, kto może być kierowcą obserwowanego samochodu oraz czego mogą się po nim spodziewać, a wszystko stosownie do zakodowanego schematu interpretacyjnego bądź przez odwołanie do stereotypu.

Ważnym kryterium oceny dokonywanej podczas wzajemnych identyfikacji kierowców jest charakterystyka osoby siedzącej za kierownicą - jej płeć, wiek, elementy ubioru czy aparycja. Przy czym pamiętać należy, że zarówno sposób jazdy, jak i samochód tworzą z osobą kierowcy pewną swoistą hybrydę interpretacyjną.

Patrzą na samochód ważne jest, żeby zobaczyć, kto to prowadzi i to daje jakby petniejszy obraz - wiesz, jak zobaczysz starego dziadka $w$ orurowanym BMW, to jednak nie posadzisz go, że jest totalnym piratem, a możliwe, że jest takim maniakiem, który lubi sobie wystrajać samochód, ale jak zobaczysz młodego byczka w takim, no to już masz inne skojarzenie - na tym to polega.

Dość istotne wydaje się kojarzenie pewnych rodzajów samochodów z pewnymi typami osób, czyli na przykład samochodu sportowego z osobą młodą, pewne napięcie czy dysonans interpretacyjny zaś może wywołać osoba starsza $\mathrm{w}$ takim samochodzie. Jednocześnie młody wiek kojarzony jest często $z$ szybką i agresywną jazdą, a osoby starsze $z$ jazdą raczej wolniejszą, by nie rzec flegmatyczną. Niebagatelną rolę odrywają tu pewnie stereotypy, które dostarczają cech uogólnianych na całą kategorię osób. To takie swoistego rodzaju wnioskowanie z prób niereprezentatywnych, czyli ludzka skłonność do uogólniania własnych ograniczonych doświadczeń, nawet jeśli jest się świadomym ich tendencyjności (Aronson, Wilson, Akert 1997, s. 157).

Potwierdzeniem istnienia przewodnich motywów identyfikacji mogą być dostrzeżone klasyfikacje czy typizacje.

Stosuje - niedzielny kierowca [...] i powolniak [...] do powolniaków zaliczam na przykład tych, którzy długo się zastanawiaja, gdzie stanać, czy zajać miejsce parkingowe czy jechać dalej, po prostu stoja i myśla, co mnie doprowadza do goraczki.

Klasyfikacje stosowane przez kierowców wskazują, jak ważny dla oceny innych kierowców jest sposób bądź styl jazdy - to przede wszystkim na podstawie tego wskaźnika dokonują oni typizacji innych kierujących. Ów wskaźnik 
łączony jest czasem z wiekiem, rzadko zaś z pojazdem. Potwierdza to zatem wcześniejsze konstatacje, że styl czy sposób jazdy jest komunikatem bardzo bogatym $\mathrm{w}$ treści.

Na koniec przedstawię kilka najbardziej powszechnych stereotypów dotyczących kierowców. Należy przyjąć, że są one ważnym elementem wzajemnych interakcji oraz wzajemnego postrzegania się wśród kierowców.

Najpowszechniejsze to na pewno stereotypy młodego kierowcy, starszego kierowcy oraz kobiety kierowcy. Młodych kierowców pozostali stereotypowo uznają za niebezpiecznych piratów drogowych, stwarzających szybką jazdą zagrożenie zarówno dla siebie, jak i dla pozostałych kierujących. Często elementem takiego wizerunku jest drogi samochód, będący, $\mathrm{w}$ przeświadczeniu badanych, prezentem od rodziców.

Negatywnie oceniam mtodych kierowców $w$ dobrych samochodach. Mam uraz do takich kierowców, bo wydaje mi się, że sa kiepskimi kierowcami, a mają dobre szybkie samochody.

Starszych kierowców często uznaje się za tych, którzy tamują ruch, spowalniają go i czynią mniej płynnym.

Jak widzę starszego kierowcę, to spodziewam się [...], że może jechać wolno albo jak widzę, że w środku lata jedzie w berecie.

Kobiety z kolei mają jeździć niepewnie i niezrozumiale.

Wydaje mi się, że $w$ dużej mierze kobiety sa gorszymi kierowcami, chociaż jeżdża, powoduja mniej wypadków, więc może ostrożniej, ale często jest tak, że nie sposób przewidzieć ich sposobu myślenia i reakcji $w$ danej sytuacji [...] wiem, że $w$ każdej chwili ta kobieta może wykonać jakiś dziwny manewr.

Stereotypy są zapewne ważnym elementem wzajemnych identyfikacji czy postaw. Upraszczają i ekonomizują procesy poznawcze - wystarczy spojrzenie, by zidentyfikować obiekt; redukują nadmiar informacji — kiedy zidentyfikowany zostanie obiekt odpowiadający schematowi, pozostałe jego cechy przestają mieć znaczenie, co ułatwia, czy może ma ułatwiać, przewidywalność zachowań innego kierowcy (Łukaszewski, Weigl 2001, s. 48-49). Ich działanie wzmacnia występująca w ruchu drogowym presja czasowa, niejako konieczność automatycznego przetwarzania informacji i percepcji nieznanych sobie osób, co sprzyja odwołaniu się do gotowych schematów (Łukaszewski, Weigl 2001, s. 50-51). Stąd też wyrazistość jednostek postrzeganych stereotypowo - dychotomie: stary versus młody oraz kobieta versus mężczyzna (Łukaszewski, Weigl 2001, s. 50). Stereotypy, często dość negatywne, są ważnym elementem drogowego mainstreamu.

Samochód to przede wszystkim środek transportu, środek do przemieszczania się, użyteczne narzędzie. Jednocześnie może być azylem, pozwala czuć się 
wolnym bądź niezależnym, jest spełnieniem marzeń i przedmiotem dającym przyjemność. Bywa wyznacznikiem pozycji czy statusu społecznego, drugim domem, dorobkiem całego życia, lokatą kapitału, przedłużeniem męskości, hobby czy wręcz sposobem na życie, dzieckiem, członkiem rodziny, obiektem uczuć, wreszcie sensem życia ${ }^{8}$. Jest więc nośnikiem bardzo wielu znaczeń, wyznacznikiem postaw wobec siebie czy sposobów postrzegania innych. Ludzie przemieszczają się samochodami w ciągłym ruchu ulicznym, tworząc swoisty tłum współdziałający według pewnych zasad normatywnych oraz zwyczajowych sprawiających, że jednostki komunikują się ze sobą i wchodzą w różnego rodzaju interakcje, które są ważnym elementem świata ich codziennej rzeczywistości. Jest to fragment świata społecznego - kultura, w której funkcjonują reguły porządku społecznego i komunikacji.

Owa komunikacja jest w oczywisty sposób ograniczona sekundowymi możliwościami jej nawiązania, wszelkimi dodatkowymi bodźcami docierającymi do kierowcy zarówno $z$ zewnątrz samochodu, jak i $z$ jego wnętrza, swoistą redundancją, czyli powielaniem znaków oznaczających to samo, a także samą strukturą czy budową samochodu jako przedmiotu materialnego - jest przecież nieprzeźroczysty i $\mathrm{w}$ zasadzie dźwiękoszczelny. Ale kierowcy próbują. Wykorzystują możliwości samochodu, używając świateł czy klaksonu, stosują język gestów czy mimikę, ale także wysyłają mniej świadome komunikaty zawarte $\mathrm{w}$ sposobie czy stylu jazdy. Jednak ruch drogowy, $z$ uwagi na tempo, przelotność czy efemeryczność spotkań i brak możliwości zadawania pytań, nie pozwala na wykorzystywanie więcej niż kilku, być może kilkunastu sposobów przekazywania informacji. Te podstawowe komunikaty są powszechnie rozumiane, rozpoznawania sensu kilku innych trzeba się uczyć dłużej, pozostałe często pozostają niezrozumiałe bądź niezauważone przez mniej doświadczonych czy mniej uważnych kierujących. Kierowcy komunikują się w sposób bardzo ograniczony, a tematem owych „rozmów” często bywa ostrzeżenie czy gest uprzejmości, choć dużo tu też złośliwości i przytyków. Jednocześnie niektórzy próbują przekazać jakieś informacje o sobie, swoim stylu życia czy światopoglądzie, przyozdabiając, przerabiając czy doznakowując swoje samochody, jednak z reguły są to komunikaty kierowane raczej do podobnych sobie niż do ogółu. Zrozumieniu sprzyja kontekst sytuacyjny - im bardziej jest typowy i powszechny, tym łatwiejsze są interpretacje komunikatów, które kierowcy sobie przekazują. Istnieje kanon obejmujący kilku reguł, prawideł czy szablonów, które znają i rozumieją w zasadzie wszyscy kierowcy, które odczytują według podobnych schematów interpretacyjnych. W sytuacjach mniej oczywistych wiadomości, które kierowcy próbują sobie przekazać, stają się niezrozumiałe bądź mniej zrozumiałe.

8 Określenia pochodzą z wcześniej przywołanych badań. 
Ruch drogowy jest siecią wielokierunkowych interakcji, których partnerzy nieustannie się zmieniają i modyfikują swe działania. W tej przestrzeni realizują się pewne stosunki społeczne, $z$ jednej strony regulowane normatywnie, $z$ drugiej zaś podlegające ogólnym zasadom porządku społecznego. Komunikacja jest jednym $z$ głównych elementów ów porządek tworzących, a dla sprawnego współegzystowania w ruchu drogowym należy opanować jej zasady — drogą wtórnej socjalizacji przyjąć rolę społeczną kierowcy, która wdrukowana zostaje $z$ całym bagażem przekonań czy stereotypów. W toku procesu uczenia się kierowca poznaje pewne schematy kulturowe, pewne zachowania społecznie usytuowane, dowiaduje się też, na czym polega drogowy konformizm. Przestrzeń interakcji zachodzących między kierowcami jest odzwierciedleniem, nieco tylko zmodyfikowanym, sieci interakcji zachodzących między ludźmi w ogóle. Nie tworzy się tu może żadna organizacja czy struktura, jednak coś na kształt środowiska społecznego, czyli zbioru podobnych pozycji i ról — na pewno. Z pewnością też powstają - czy raczej są ustanawiane przez ludzi - jakieś reguły gry, z jednej strony normatywne, $z$ drugiej zaś obyczajowe czy moralne, które umożliwiają współdziałanie, a co za tym idzie - zaistnienie owego porządku czy ładu społecznego.

Siła poczucia wspólnoty w danej rzeczywistości bierze się z przewidywalności warunków codziennego obcowania między ludźmi. Kiedy owa przewidywalność zawodzi, pojawia się nieprzejrzystość, chaotyczność życia społecznego, dezorientacja, czyli opisywana przez Anthony'ego Giddensa (2001, s. 50-55) niepewność. Kierowcy starają się rozumieć pozostałych uczestników ruchu drogowego, ale niekiedy ich zachowania mimo wszystko zaskakują, burzą owo poczucie wspólnoty. W tym sensie jazda samochodem może być przykładem nowego obszaru ryzyka Giddensowskiego świata wysoko rozwiniętej nowoczesności.

Na koniec należy zaznaczyć, że uczestnictwo w ruchu drogowym jest przede wszystkim obcowaniem wzajemnym ludzi. Świat społeczny ulic oraz dróg to świat tworzony i opanowany przez ludzi, a nie przez maszyny. To ludzie tworzą kulturę drogową i ludzie w niej uczestniczą — samochody są tu jedynie pewnymi środkami pośredniczącymi z jednej strony i wytworami tejże kultury $z$ drugiej. A kultura, w pewnym wąskim jej rozumieniu, polega na komunikowaniu, na nawiązywaniu łączności między ludźmi, bez czego nie byłoby społeczeństwa (Golka 2008, s. 3-4, 47), a także wzorów myślenia charakterystycznych dla danego czasu. W przestrzeni tych wzorów funkcjonują schematy komunikacji i interakcji wzajemnych między kierowcami samochodów.

\section{BIBLIOGRAFIA}

Aronson Elliot, Wilson Timothy D., Akert Robin M., 1997, Psychologia społeczna. Serce $i$ umyst, tłum. Anna Bezwińska i in., Zysk i S-ka, Poznań. 
Berger Peter L., 2000, Społeczeństwo w człowieku, w: Halina Mielnicka (red.), Socjologia wychowania. Wybór tekstów, Wydawnictwo Stachurski, Kielce.

Dant Tim, 2007, Kultura materialna $w$ rzeczywistości społecznej. Wartości, działania, style życia, tłum. Janusz Barański, Wydawnictwo Uniwersytetu Jagiellońskiego, Kraków.

Drozdowski Rafał, Krajewski Marek (red.), 2008, Wyobraźnia społeczna. Horyzonty —źródła - dynamika. Uwarunkowania strategii dostosowawczych wspótczesnego społeczeństwa polskiego. Studium socjologiczne, Wydawnictwo Naukowe UAM, Poznań.

Edensor Tim, 2004, Tożsamość narodowa, kultura popularna i życie codzienne, tłum. Agata Sadza, Wydawnictwo UJ, Kraków

Giddens Anthony, 2001, Nowoczesność i tożsamość. „Ja” i społeczeństwo w epoce późnej nowoczesności, tłum. Alina Szulżycka, Wydawnictwo Naukowe PWN, Warszawa.

Goffman Erving, 2006, Porzadek interakcyjny, w: Aleksandra Jasińska-Kania, Lech M. Nijakowski, Jerzy Szacki, Marek Ziółkowski (red.), Wspótczesne teorie socjologiczne, Scholar, Warszawa.

Goffman Erving, 2008, Zachowanie w miejscach publicznych. O społecznej organizacji zgromadzeń, tłum. Olga Siara, Wydawnictwo Naukowe PWN, Warszawa.

Golka Marian, 2007, Socjologia kultury, Scholar, Warszawa.

Golka Marian, 2008, Bariery w komunikowaniu i społeczeństwo (dez)informacyjne, Wydawnictwo Naukowe PWN, Warszawa.

Hałas Ewa, 2007, Symbole $i$ społeczeństwo. Szkice z socjologii interpretacyjne, Wydawnictwo Uniwersytetu Warszawskiego, Warszawa.

Kaufmann Jean-Claude, 2004, Ego. Socjologia jednostki. Inna wizja człowieka i konstrukcji podmiotu, tłum. Krzysztof Wakar, Oficyna Naukowa, Warszawa.

Kofta Mirosław, Jasińska-Kania Aleksandra (red.), 2001, Stereotypy i uprzedzenia. Uwarunkowania psychologiczne i kulturowe, Scholar, Warszawa.

Krajewski Marek, 2005, Wstęp, w: Marek Krajewski, Maja Brzozowska, W stronę socjologii przedmiotów, Wydawnictwo Naukowe UAM, Poznań.

Krajewski Marek, 2008, Motywy przewodnie i przedmioty, w: Rafał Drozdowski, Marek Krajewski (red.), Wyobraźnia społeczna. Horyzonty — źródta-dynamika. Uwarunkowania strategii dostosowawczych wspótczesnego społeczeństwa polskiego. Studium socjologiczne, Wydawnictwo Naukowe UAM, Poznań.

Krajewski Marek, Brzozowska Maja (red.), 2005, W stronę socjologii przedmiotów Wydawnictwo Naukowe UAM, Poznań.

Łukaszewski Wiesław, Weigl Barbara, 2001, Stereotyp stereotypu czy prywatna koncepcja natury ludzkiej, w: Mirosław Kofta, Aleksandra Jasińska-Kania (red.), Stereotypy $i$ uprzedzenia. Uwarunkowania psychologiczne $i$ kulturowe, Scholar, Warszawa

Pietrowicz Krzysztof, 2004, Nasze gadżety codzienne albo o plynności symboli statusu, w: Tomasz Szlendak, Krzysztof Pietrowicz (red.), Na pokaz. O konsumeryzmie w kapitalizmie bez kapitatu, Wydawnictwo Uniwersytetu Mikołaja Kopernika, Toruń.

Szlendak Tomasz, Pietrowicz Krzysztof (red.), 2004, Na pokaz. O konsumeryzmie w kapitalizmie bez kapitału, Wydawnictwo Uniwersytetu Mikołaja Kopernika, Toruń.

Sztompka Piotr, 2007, Zaufanie. Fundament społeczeństwa, Znak, Kraków.

Sztompka Piotr, Bogunia-Borowska Małgorzata (red.), 2008, Socjologia codzienności, Znak, Kraków.

Urry John, 2008, Życie za kótkiem, w: Piotr Sztompka, Małgorzata Bogunia-Borowska (red.), Socjologia codzienności, Znak, Kraków. 
Zimbardo Philip G., Leippe Michael R., 2004, Psychologia zmiany postaw $i$ wptywu spotecznego, tłum. Paweł Kwiatkowski, Zysk i S-ka, Poznań.

\title{
DAILY LIFE IN THE CAR. PATTERNS OF INTERACTION AND MUTUAL PERCEPTION OF DRIVERS FROM THE PERSPECTIVE OF THE SOCIOLOGY OF EVERYDAY LIFE
}

\begin{abstract}
Summary
The article contains an attempted reconstruction of the manners of communication which occur between the drivers of cars, in other words the characteristic methods of communicating information and the manners of their interpretation. The analysis, conducted from the perspective of the sociology of everyday life, includes that which constantly occurs in the social conditions on the roads, the interaction between drivers, their communication, their mutual influence on each other, attitudes and stereotypes. In particular the author demonstrates the specific communicative code of drivers, defines the motives for their behaviour and the means of their interpretation, and also the patterns of interaction and mutual perception. He considers whether drivers really do co-exist in the space of the same symbols and significances, if they really do mutually communicate and into what manner of interactions they enter.
\end{abstract}

\section{Key words/słowa kluczowe}

sociology of everyday life / socjologia życia codziennego; car / samochód; driver / kierowca; schemes of interaction / schematy interakcji; interpretive schemes / schematy interpretacji; communicative codes / kody komunikacyjne 